\title{
Pola Permainan Alat Musik Keroncong dan Tenor di Orkes Keroncong Irama Jakarta
}

\author{
Hery Supiarza ${ }^{1}$, Irwan Sarbeni \\ Program Studi Film dan Televisi, FPSD, Universitas Pendidikan Indonesia
}

\section{Deni Irmawan}

SMP Negeri 1 Jonggol, Kabupaten Bogor, Jawa Barat

\begin{abstract}
The Musical Pattern of Keroncong and Tenor Instruments in the Keroncong Irama Orchestra Jakarta. This study discusses the musical pattern of keroncong and tenor instruments and their application to the songs "Cente Manis" and "Sambel Cobek". Both of these instruments are the identity of the Jakarta style of keroncong. The study was conducted with a descriptive qualitative approach. The data was collected through observation, interviews, and documentation. Based on the results of the study, it was found that the origin term of keroncong musical instrument came from the sound of the instrument itself. The term of tenor refers to the term for the highest male voice. The techniques of playing musical instruments of keroncong and tenor were also found, namely rasguaedo (prung), strumming, arpeggio, and by strumming on each string one by one. The techniques of playing the keroncong and tenor instruments include double ankle, double back play, old format and style. The four patterns of musical playing depend on the played songs and the agreement of the personnel.
\end{abstract}

Keywords: cente manis; tenor; Irama Jakarta

\begin{abstract}
ABSTRAK
Penelitian ini mendiskusikan pola permainan alat musik keroncong dan tenor serta penerapannya pada lagu "Cente Manis" dan "Sambel Cobek". Kedua alat musik ini merupakan identitas keroncong gaya Jakarta. Penelitian dilakukan dengan pendekatan kualitatif deskriptif dan data dikumpulkan melalui observasi, wawancara, dan dokumentasi. Berdasarkan hasil penelitian ditemukan bahwa asal mula istilah alat musik keroncong berasal dari bunyi alat musik itu sendiri. Istilah tenor merujuk pada istilah suara laki-laki tertinggi. Ditemukan juga teknik permainan alat musik keroncong dan tenor yaitu teknik rasguaedo (prung), strumming, arpeggio dan dengan cara dipetik satu-satu pada setiap senar. Teknik memainkan alat musik keroncong dan tenor tersebut meliputi pola permainan dobel engkel, dobel balik, format dan gaya lama. Permainan keempat pola tersebut bergantung pada lagu yang akan dibawakan dan kesepakatan para personilnya.
\end{abstract}

Kata kunci: cente manis; tenor, Irama Jakarta

\section{Pendahuluan}

Musik keroncong sebagai salah satu budaya Indonesia sejak dulu telah diwarnai dengan keragaman karya dan dinamika wacana. Keberagaman ini perlu diperkenalkan kepada masyarakat luas, agar kesenian daerah atau seni tradisi tetap dikenal dan digemari oleh masyarakat pendukungnya (Kautzar, 2019).

Dari berbagai fenomena yang tampak, penamaan karya itu bukan hanya sebatas kepada arti musik keroncong saja, tetapi lebih bermakna sebagai suatu identitas dalam perkembangan musik keroncong yang mempunyai paradigma estetika

\footnotetext{
Alamat korespondensi: Prodi Film dan Televisi, Fakultas Pendidikan Seni dan Desain, Universitas Pendidikan Indonesia. Jln. Dr. Setiabudi 229, Bandung, Jawa Barat, HP. 081321063919, E-mail: herysupiarza@upi.edu.
} 
sendiri. Paradigma menurut Kuhn (dalam Nurkhalis, 2012) adalah proses pembentukan konsep, model, atau pandangan bersama terhadap suatu fakta. Bila merujuk definisi tersebut, paradigma estetik yang dimaksud dalam penelitian ini adalah suatu konsep atau model estetik yang tengah dianut bersama. Konsep dan model estetik itu oleh penggiat musik keroncong dibangun untuk membangkitkan dan mewujudkan kembali konsep dan sistem musik keroncong. Hal ini untuk melestarikan dan mengembangkan musik keroncong sebagai identitas musik Indonesia (Alfian, 2013)

Berdasarkan berbagai konsep musik keroncong yang berkembang, dapat dikenali gaya-gaya permainan yang berdasarkan pada repertoar musik keroncong. Ada beberapa pendapat mengenai repertoar musik keroncong ini. Keroncong dibagi menjadi empat jenis, yaitu: keroncong asli, stambul, langgam keroncong, langgam Jawa, dan keroncong beat (Margaret J. Kartomi, David Goldsworthy, Catherine Falk, 1978). Philip B. Yampolsky (2010) membagi menjadi empat yaitu keroncong asli, stambul, langgam dan langgam Jawa. Harmunah (1996) membagi menjadi empat bagian besar, yaitu: keroncong asli, stambul, langgam, dan keroncong ekstra. Secara periodisasi Lisbijanto (2013) membagi menjadi empat masa: (1) masa Keroncong Tempo Doeloe (1880-1920), (2) masa Keroncong Abadi (1920-1959), (3) masa Keroncong Modern (1959-2000), (4) Keroncong Milenium (2000-sekarang).

Konstruksi keroncong di era milenium dapat diketahui aktivitasnya melalui artikel "Prospek dan Masa Depan Musik Keroncong Anak Muda di Kota Bandung", (Supiarza, H. Sobarna, C. Sukmayadi, Y . Mulyadi, 2018). Gejala ini secara menyeluruh menjadi rujukan para seniman musik keroncong di Indonesia. Musik keroncong adalah musik yang mempunyai karakter unik karena bisa beradaptasi dengan kebudayaan-kebudayaan yang ada di Indonesia karena keroncong memiliki sifat musik rakyat (Supiarza, H. Sobarna, C. Sukmayadi, Y. Mulyadi, 2018). Berdasarkan kajian awal, pada kenyataannya gaya tersebut mengalami perkembangan dengan adanya pengaruh gaya irama lain, seperti latin, dangdut, jazz, dan rock. Salah satunya upaya anak muda keroncong di Kota
Bandung mengkolaborasikan musik keroncong dengan musik reaggae dengan menciptakan jenis keroncong baru bernama "Jamaican Sound Keroncong” (Supiarza, H. Sobarna, 2019).

Sejak awal keberadaannya, musik keroncong tercipta dari hasil perpaduan kebudayaan sehingga terjadi percampuran elemen-elemen dilakukan secara sadar kemudian membentuk musik yang baru. Percampuran elemen seperti ini disebut hibridasi (Rachman \& Utomo, 2017). Dalam penciptaan musik, hibridisasi pada dasarnya menjadi sifat yang inheren (melekat) berupa pengadopsian dan pencampuran elemen-elemen musikal dari sumber-sumber yang memiliki gaya berbeda atau yang baru, (Siagian, 2013). Akan tetapi hibridasi ini tidak semata-mata proses percampuran sembarangan, ada nilai-nilai penting di dalam proses percampurannya (Laksono, 2015).

Josep Martí berpandangan bahwa hakekat nilai-nilai musik sesungguhnya "terletak pada kapasitas keterpaduan [estetika musik], yang diciptakan dengan cara mencampur berbagai elemen [gaya] yang diambil dari berbagai unsur" (Marti, 2014). Dalam musik hibrid, elemen-elemen itu kemudian bercampur menjadi satu bagian yang tidak terpisahkan (Sunarto, 2013).

Musik keroncong merupakan salah satu dari sekian banyak musik popular yang ada di Indonesia (Alfian, 2013). Mengenai peristilahan musik populer, dikatakan oleh Mack (1995:20), "dari segi peristilahan kami usulkan bahwa istilah "musik populer" diartikan untuk segala musik yang sedang berkembang sejajar dengan perkembangan media audio visual, artinya "music entertainment" di Amerika dari awal abad ini sampai sekarang". Selanjutnya, Mack mengatakan bahwa, pengertian mengenai musik populer ini sebaiknya didahului dengan pemahaman masalah folklor dan musik rakyat pada umumnya, sehingga dapat dibedakan berbagai hal yang penting terkait dengan istilah tersebut. Musik rakyat atau folklor berada di seluruh dunia, akan tetapi musik folklor bukanlah musik yang bersifat massa dalam pengertian komersial, (walaupun kadang-kadang juga sudah "di-massakan"), melainkan lagu rakyat yang tetap berada di lingkup tradisi dan fungsi dalam suatu lingkungan tertentu sebagai lagu pergaulan, suasana nostalgia, 
lagu anak-anak (Lei Ouyang Bryant, 2005). Dalam peristilahan popular, dalam musik keroncong diketahui adanya hubungan atau keterkaitan karena unsur popularitas melekat pada musik ini apabila ditinjau dari sudut sejarahnya, terutama di masa awal zaman kolonial ketika industri rekaman pertama berkembang di Indonesia pada tahun 1920-an, lihat (Philip Bradford Yampolsky, 2013) dalam Music and media in the Dutch East Indies: Gramophone records and radio in the late colonial era, 1903-1942). Budaya musik keroncong sangat erat kaitannya dengan alat musik peninggalan bangsa Portugis yaitu Cavaquinho. Cavaquinho merupakan instrumen musik yang senantiasa dibawa oleh para pemukim, imigran, dan pelaut bangsa Portugis kemanapun mereka pergi, sehingga memperoleh berbagai nama." (Ganap, 2000). Alat musik ini merupakan embrio dari musik keroncong yang berkembang saat ini.

Salah satu jenis musik keroncong yang menarik bagi peneliti yaitu musik keroncong Jakarta. Berdasarkan observasi awal yang telah dilakukan dapat disimpulkan bahwa satu-satunya grup yang masih eksis memainkan musik keroncong Jakarta adalah Orkes Keroncong Irama Jakarta. Orkes Keroncong Irama Jakarta cukup popular di kalangan penggiat dan penikmat musik keroncong dengan pengalaman tampil di beberapa stasiun radio dan televisi.

Terdapat beberapa hal yang cukup menarik bagi peneliti ketika berbicara tentang Orkes Keroncong Irama Jakarta, salah satunya adalah irama musik keroncong yang dimainkan. Grup keroncong ini memiliki keunikan pada sisi irama yang membedakannya dengan irama musik keroncong pada umumnya, irama ini berkaitan erat dengan keberadaan alat musik keroncong dan tenor. Perbedaan irama yang terdapat dalam Orkes Keroncong Irama Jakarta ini dikarenakan oleh adanya alat musik keroncong dan tenor yang dimainkan dengan teknik rasguaedo dan strumming. Selain itu, musik keroncong jenis ini cenderung memainkan irama musik yang relatif cepat, sehingga kedua hal tersebut yang menjadikanya berbeda dengan jenis keroncong lainnya.

Penamaan alat musik dalam keroncong Jakarta ini unik, yaitu ada istilah keroncong dan tenor. Keroncong sebagai bentuk kesenian popular masa itu bergantung pada media masa, sehingga posisinya lebih berkuasa dari kesenian tradisi (Harwanto, 2018). Yang dimaksud kesenian tradisi adalah musik asli yang ada di setiap wilayah Republik Indonesia ini, seperti gamelan Sunda, Jawa dan Bali (Widhyatama, 2012)

Keroncong merupakan istilah yang digunakan untuk menamakan cuk dan tenor merupakan istilah yang digunakan untuk menamakan cak. Hal ini menumbuhkan asumsi bahwa penamaan alat musik keroncong diambil dari bunyi yang dihasilkan dari alat musik itu sendiri sehingga instrumen tersebut dinamakan keroncong. Selanjutnya, penamaan untuk alat musik tenor diambil karena wilayah suara yang dimiliki alat musik tenor lebih tinggi dibandingkan dengan alat musik keroncong. Selain itu, juga ditemukan keunikan pada sistem nada dan senar yang digunakan pada keroncong dan tenor. Bentuk keroncong menyerupai gitar berukuran kecil berdawai tiga yang berbahan nilon dengan susunan nada E-G-B. Sementara itu, bentuk alat musik tenor menyerupai gitar berukuran kecil berdawai tiga yang berbahan logam namun dengan susunan nada yang berbeda, yaitu B-Fis-D. Fungsi dari kedua instumen ini adalah sebagai pemegang irama. Kemudian cara memainkannya keduanya, baik alat musik keroncong maupun tenor, berbeda. Alat musik keroncong dimainkan dengan cara digaruk (rasguaedo) hampir sama dengan cara memainkan prounga dan macina pada Krontjong Toegoe, sedangkan alat musik tenor dimainkan hampir sama dengan cara memainkan cak pada keroncong gaya Surakarta (Solo). Keunikan ini menarik untuk dikaji lebih dalam tentang musik keroncong Jakarta pada O.K. Irama Jakarta. Berdasarkan latar belakang tersebut, tujuan paparan ini untuk mengkaji pola permainan alat musik keroncong dan tenor di Orkes Keroncong Irama Jakarta.

Metode penelitian ini dilakukan dengan pendekatan kualitatif deskriptif. Yakni penelitian yang berusaha mendeskripsikan suatu gejala, peristiwa, kejadian yang terjadi saat sekarang, (Ratna, 2016). Partisipan dalam penelitian ini yaitu para pemain yang tergabung dalam grup musik Orkes Keroncong Irama Jakarta, khususnya Harun Rusli dan Kelik S. Ponco. 
Partisipan penelitian ini diambil karena mereka memiliki informasi yang berkaitan dengan alat musik keroncong dan tenor, serta informasi mengenai perkembangan Orkes Keroncong Irama Jakarta dari awal berdiri hingga sekarang. Teknik pengumpulan data yang digunakan dalam penelitian ini adalah melalui kegiatan observasi, wawancara, studi literature dan studi dokumentasi (Aan Prabowo, 2013).

Pada kegiatan observasi, peneliti melakukan pengamatan tentang teknik memainkan alat musik keroncong dan tenor pada Orkes Keroncong Irama Jakarta yang meliputi pembedaan alat musik keroncong dan tenor, cara memainkan alat musik keroncong dan tenor, pola yang terdapat dalam keroncong Jakarta serta penerapan pola permainan keroncong dan tenor.

Pada kegiatan wawancara, peneliti melakukan wawancara tentang teknik memainkan alat musik keroncong dan tenor, meliputi cara memainkan alat musik keroncong dan tenor, informasi-informasi terkait alat musik keroncong dan tenor, pola memainkan alat musik keroncong dan tenor serta penerapan pola permainan alat musik keroncong dan tenor terhadap karya yang dibawakan.

Dalam studi dokumentasi dan literatur, selain dari buku, jurnal, serta artefak lainnya, peneliti mengambil beberapa contoh lagu yang ditranskripkan berdasarkan contoh lagu yang sering dimainkan oleh Orkes Keroncong Irama Jakarta, yaitu: lagu "Cente Manis" dan lagu "Sambel Cobek”.

\section{Perkembangan Musik Keroncong Jakarta}

Keroncong Jakarta adalah salah satu genre musik keroncong yang berkembang di masyarakat Jakarta permainan keroncong Jakarta sejatinya merupakan hasil imitasi dari komunitas Keroncong Tugu, Brata (dalam Ganap, 2011: 127) menyatakan bahwa:

'Krontjong Toegoe yang telah dikenal di Batavia sejak abad ke delapan belas melalui penampilan mereka dalam berbagai acara pasar malam, festival kesenian rakyat, barak militer atau berkeliling dari kampung ke kampung, telah lama diimitasi bahkan diambil alih oleh kelompok masyarakat lainnya di kota Batavia. Kelompok masyarakat yag berhasil tampil adalah komunitas Indo-Belanda dari kampung Kemayoran yang kemudian dikenal sebagai komunitas Krontjong Kemajoran.'

Ada beberapa hal yang menjadi bukti keterkaitan antara musik keroncong Jakarta dengan Keroncong Tugu. Pertama, dari cara pembawaanya musik keroncong gaya ini cenderung lebih cepat (up beat); kedua, teknik memainkan alat musiknya. Perbedaanya hanya pada penamaan alat yang digunakan. Mengenai pembawaan musik keroncong gaya Jakarta ini, dikatakan Harmunah (1996: 33) bahwa:

“..alat Ukulele yang dipergunakan adalah Ukulele stem A, yang bertali empat dan dimainkan secara arpeggio (rasguaedo), sehingga menimbulkan istilah "irama kemprong".., pada pembawaan alat Banyo, permainan lebih menonjol dengan variasvariasinya. Tetapi ada pula yang hanya dimainkan dengan satu nada pada satu tali, dari akor yang sedang dimainkan.”

Semakin berkembangnya musik keroncong di Batavia menyebabkan semakin banyak grup keroncong bermunculan di Batavia, salah satunya yaitu OK Lief Java yang pada saat itu memiliki anggota sebanyak 150 orang yang beranggotakan tidak hanya dari orang-orang Jawa saja. OK Lief Java ini juga pernah didukung beberapa pemusik kawakan seperti Anni Landouw dan Ismail Marzuki, (Suadi, 2017).

Dalam perkembangannya, musik keroncong yang kini dikenal di masyarakat terpengaruh oleh kesenian daerah setempat. Seperti halnya dengan musik keroncong Jawa (Solo) yang dipengaruhi permainan gamelan Jawa, keroncong Jakarta pun dipengaruhi oleh musik yang berkembang di daerah Jakarta. Musik daerah yang mempengaruhi keberadaan musik keroncong di Jakarta adalah gambang kromong. Pengaruh musik gambang kromong atau cokek terlihat ketika orkes keroncong yang ada di Jakarta ini memainkan lagu-lagu seperti "Jali-jali" dan "Centik Manis" (B, 1979). 


\section{Alat Musik Keroncong dan Tenor}

Seperti dalam keroncong Jawa yang dikenal dengan lagu langgam Jawa dan alat musik cak cuknya (Destiana, 2012). Keroncong Tugu dikenal dengan lagu berbahasa Portugis dan machina prounga-nya, juga keroncong Jakarta yang dikenal dengan lagu-lagu yang diadaptasi dari kesenian gambang kromong dan alat musik keroncong dan tenor. Beberapa repertoar lagu yang dibawakan cenderung sama, hanya berbeda dari irama musiknya saja. Seperti lagu keroncong "Moresko", "Stambul Jampang", dan "Jali-jali". Alat musik ini memberikan identitas pada setiap jenis musik keroncong, karena selain perbedaan organologinya, juga pola permainan. Penyebutan jenis keroncong Tugu, Keroncong Jakarta, Keroncong Solo, keroncong Tempo Dulu salah satunya karena pengaruh pola permainan alat musik. Hal ini dikatakan (Heins, 1975) "Penggunaan alatalat yang berbeda tersebut menyebabkan cara permainan dan hasil yang berbeda juga. Dilihat dari komposisi alat musiknya, dalam musik keroncong Jawa digunakan alat music, antara lain: cak, cuk, gitar, cello, bass, violin dan flute".

Berbeda halnya dengan instrumen yang digunakan pada Keroncong Tugu, yang pada awal berdirinya, hanya mempergunakan beberapa instrumen saja yaitu berupa machina, prounga dan jittera kemudian setelah itu mengalami perkembangan dengan masuknya instrumen lain seperti cello, violin dan bass. "Namun kini alat

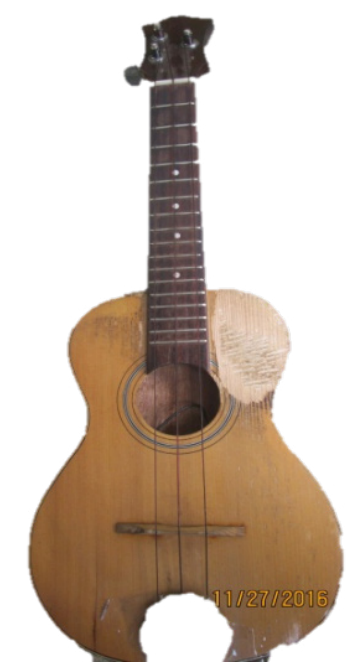

Gambar 1. Alat musik Keroncong. (Sumber: Dokumentasi Peneliti, 2016) musik umum yang digunakan pada orkes-orkes Keroncong Tugu, antara lain: biola, gitar, machina, prounga, cello dan bass" (Supiarza, H. Sobarna, C. Sukmayadi, Y . Mulyadi, 2018). Kini alat musik umum yang digunakan pada orkes keroncong Jakarta adalah alat musik keroncong, alat musik tenor, cello, biola, gitar, bass dan flute.

Alat musik keroncong merupakan alat musik yang menyerupai gitar berukuran kecil berdawai nilon dengan sistem nada E-B-G dan merupakan salah satu alat musik yang digunakan dalam musik keroncong Jakarta selain cello, bass, gitar, flute dan biola. Istilah keroncong diambil karena bunyi dari alat musik ini apabila dimainkan berbunyi 'crong' sehingga terciptalah istilah keroncong. Dalam keroncong Jakarta penamaan alat musik ini tetap dipertahankan sampai sekarang sehingga alat yang digunakanpun tetap menggunakan istilah keroncong.

Selain alat musik keroncong, pada musik keroncong Jakarta dikenal istilah alat musik tenor. Alat musik tenor merupakan alat musik yang menyerupai gitar berukuran kecil dengan dawai yang terbuat dari bahan logam dengan sistem nada B-Fis-D atau dikenal dengan sebutan in $\mathrm{G}$. Lain halnya dengan penamaan alat musik keroncong, pernamaan alat musik tenor diambil dari istilah wilayah suara tinggi pada laki-laki. Tenor merupakan suara pria tertinggi... atau suara (jenis) alat musik yang setara dengan tenor manusia (Wijayanto \& Dwifebrianti, 2013). Bunyi yang dihasilkan dari alat musik tenor ini jauh lebih

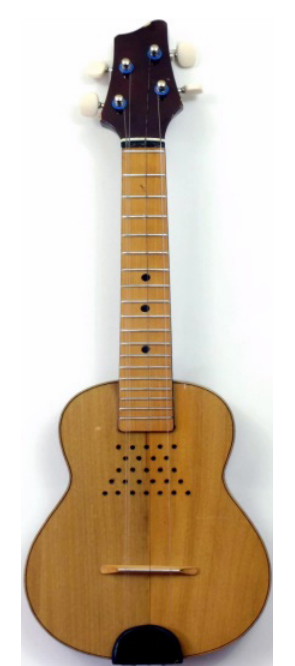

Gambar 2. Alat musik Tenor.

(Sumber: Dokumentasi Peneliti, 2016) 
tinggi dari bunyi yang dihasilkan oleh alat musik keroncong sehingga terciptalah istilah alat musik tenor pada keroncong Jakarta. Penggunaan alat musik tersebut memunculkan perbedaan antara keroncong Jakarta dengan keroncong Jawa (Solo) dan Tugu. Dalam permainannya alat musik keroncong dan tenor selalu dimainkan saling bersahut-sahutan.

\section{Teknik Permainan Alat Musik Keroncong dan Tenor}

Ada beberapa teknik yang sering digunakan dalam permainan alat-alat keroncong, salah satu teknik yang sering digunakan, antara lain: rasguaedo dan strumming.

Teknik rasguaedo adalah teknik permainan gitar flamenco (Supriando, 2016), berupa petikan beruntun dengan mempergunakan urutan, berupa jari kelingking, jari manis, jari tengah, jari telunjuk, dan kadang-kadang diikuti dengan ibu jari, dimulai dari dawai 6 hingga dawai 1; sedangkan teknik strumming adalah teknik membunyikan beberapa senar gitar sekaligus secara serentak dengan menggunakan jari atau plectrum. Ada yang menyebutnya teknik kocokan atau genjrengan... gerakan dasarnya hanya ada dua, yaitu: kearah tanah (down stroke) dan ke arah wajah gitaris (upstroke) (Kristianto, 2007).

Penggunaan teknik ini tergantung kepada penggunaan gaya musik keroncong yang dimainkan. Pada Keroncong Tugu, teknik rasguaedo lebih sering digunakan dalam memainkan machina maupun prounga, hanya berbeda secara metris saja. Berbeda dengan keroncong Jawa, teknik permainan tersebut menjadi jarang digunakan, lihat permainan cuk pada keroncong Jawa, "dari permainan rasguaedo menjadi petikan repetisi pada satu senar berdasarkan akor yang dibawakan.” (Harmunah, 1996: 26). Akan tetapi, penggunaan teknik strumming masih digunakan pada keroncong jenis ini, terutama dari cara memainkan instrumen cak.

Dalam keroncong Jakarta selain berbeda dari segi istilah yang digunakan untuk menamakan alatnya, cara memainkannya pun berbeda pula. Cara memainkan alat musik keroncong yaitu dimainkan dengan teknik rasguaedo (prung). "Pembawaan dari alat ini dipetik secara arpeggio atau menurut istilah dalam permainan gitar disebut "rasguaedo" (Spanyol), dengan alat plectrum." (Harmunah, 1996: 26). Cara memainkan keroncong ini sering juga dikatakan irama kemprong, karena cara memainkannya di garuk keempat talinya sehingga menimbulkan bunyi "kemprong-kemprong" (B, 1979). Untuk alat musik tenor sendiri dimainkan dengan cara dipetik satu-satu pada setiap senar dalam akor yang sedang dimainkan, sering alat ini hanya mempergunakan satu senar saja, yang dipetik satu-satu dengan maksud untuk mengimbangi pukulan Ukulele yang dimainkan secara "rasguaedo".

\section{Fungsi Alat Musik Keroncong dan Tenor dalam Keroncong Jakarta}

Secara umum, fungsi dari alat musik keroncong dan tenor hampir sama dengan fungsi instrumen cak dan cuk pada gaya keroncong Jawa, serta machina dan prounga pada Keroncong Tugu yaitu sebagai pemegang ritmis dan pembawa irama. "Sama dengan alat Ukulele, termasuk keluarga instrumen tali petik, dan dalam musik keroncong berfungsi sebagai pemegang ritmis pula." (Harmunah, 1996: 22). Hanya saja yang membedakannya adalah irama yang dihasilkan dari kedua alat ini, pada pola permainannya keroncong dan tenor cenderung lebih cepat (up beat).

\section{Orkes Keroncong Irama Jakarta}

Berdasarkan observasi peneliti menemukan bahwa satu-satunya grup keroncong yang kini tetap eksis memainkan keroncong Jakarta adalah Orkes Keroncong Irama Jakarta. Hal tersebut terbukti dalam penampilannya di beberapa stasiun televisi, radio, dalam peribadatan di gereja, dan acara-acara besar lainnya, seperti jambore 1000 lagu keroncong di Semarang tahun 2013. Nama Orkes Keroncong Irama Jakarta dicetuskan pertama kali pada saat tampil dalam acara Gebyar Musik Keroncong di TVRI tahun 2008. Nama tersebut lahir karena tuntutan dari pihak penyelenggara acara, yaitu TVRI yang mengharuskan para personil dari grup ini memberikan nama pada grup keroncongnya 
dan pada akhirnya lahirlah nama Orkes Keroncong Irama Jakarta. Harun Rusli merupakan pimpinan dari grup keroncong Orkes Keroncong Irama Jakarta ini. Menurut Harun Rusli, nama tersebut diambil berdasarkan irama musik keroncong dalam keroncong Jakarta yang merupakan ciri khas dari keroncong Jakarta. Meskipun nama Orkes Keroncong Irama Jakarta lahir pada tahun 2008, namun para personil grup keroncong ini telah memainkan keroncong Jakarta sebelum adanya nama Orkes Keroncong Irama Jakarta.

Selain tampil dalam acara gebyar keroncong di TVRI pada tahun 2008, Orkes Keroncong Irama Jakarta pun pernah tampil di salah satu radio di kota Bandung pada acara Kharisma Keroncong Lita FM tahun 2012. Nama Orkes Keroncong Irama Jakarta semakin dikenal setelah tampil dalam acara Jambore 1000 lagu keroncong di Semarang tahun 2013. Menurut Agustin selaku vokalis dari Orkes Keroncong Irama Jakarta, dari sekian banyak grup keroncong yang tampil dalam acara Jambore 1000 lagu keroncong pada saat itu, hanya ada 2 grup keroncong yang berbeda dari segi irama musik keroncong yang dimainkan, yaitu Krontjong Toegoe dan Orkes Keroncong Irama Jakarta. Hal ini tentu saja menyita banyak perhatian dari para apresiator yang berapresiasi dalam acara tersebut. Orkes Keroncong Irama Jakarta ini beranggotakan generasi lanjut yang sebelumnya memang sering bermain musik keroncong bersama dalam peribadatan di gereja. Para personil dari Orkes Keroncong Irama Jakarta ini antara lain adalah Harun Rusli sebagai pemain alat musik tenor sekaligus pimpinan dari Orkes Keroncong Irama Jakarta, Rusmanto sebagai pemain alat musik keroncong, Nicolaus Payong Ola sebagai pemain bass, Cecep Sumarlin sebagai pemain gitar, Permana sebagai pemain violin, Adhi sebagai pemain cello dan Kelik S. Ponco sebagai pemain flute sekaligus arranger dalam Orkes Keroncong Irama Jakarta.

Para personil yang tergabung dalam Orkes Keroncong Irama Jakarta sekarang ini sebelumnya merupakan personil dari grup keroncong yang berbeda, dan tentu saja memliki latar belakang musik yang berbeda pula, seperti Nicolaus Payong Ola yang merupakan personil dari Krontjong Toegoe serta Cecep Sumarlin dan Agustine yang merupakan personil dari Keroncong Tugu Cafrinho, ketiganya berlatar belakang musik Keroncong Tugu. Sedikit berbeda dengan Nicolaus dan Cecep, Agustin yang merupakan penyanyi dari grup keroncong Irama Jakarta mempunyai latar belakang sebagai penyanyi dangdut, campursari bahkan band rock. Agustin memutuskan untuk bergabung dengan Orkes Keroncong Irama Jakarta pada tahun 2009 sampai sekarang. Harun Rusli sebagai pimpinan dari Orkes Keroncong Irama Jakarta, Rusmanto dan Adhie inilah yang memang berlatar belakang musik keroncong Jakarta dan juga Permana yang berlatar belakang musik keroncong Jawa (Solo). Meskipun berbeda latar belakang musik yang dimiliki setiap personilnya, kini musik yang tetap mereka mainkan adalah musik keroncong Jakarta. Selain bertujuan untuk melestarikan musik keroncong Jakarta, para personil yang tergabung dalam grup musik Orkes Keroncong Jakarta ini berkeinginan agar musik keroncong Jakarta lebih dikenal dimasyarakat tidak hanya masyarakat Jakarta saja, melainkan seluruh masyarakat Indonesia khususnya generasi muda.

Dalam Orkes Keroncong Irama Jakarta terdapat personil sekaligus berperan sebagai arranger yaitu Kelik S. Ponco merupakan arrenger sekaligus pemain flute dari Orkes Keroncong Irama Jakarta. Kelik sendiri pernah tergabung kedalam kelompok musik militer di tahun 1974. Ia juga sempat belajar beberapa alat musik tiup seperti clarinet, saxophone, dan terumpet. Bahkan, ia pernah menjadi seorang vocal director di sebuah perusahaan rekaman pada tahun 90-an. Atas pengalaman bermusik yang dimilikinya, Kelik dipercaya oleh personil Orkes Keroncong Irama Jakarta yang lain untuk menjadi seorang arranger dalam grup keroncong tersebut. Selain sebagai seorang arranger, Kelik pun berperan sebagai kurator apabila salah satu di antara personil Orkes Keroncong Irama Jakarta membuat sebuah aransemen untuk lagu yang akan dimainkan oleh Orkes Keroncong Irama Jakarta. Menurut pemaparan Kelik, Orkes Keroncong Irama Jakarta sangat membutuhkan seorang arranger. Hal tersebut dirasa perlu agar musik keroncong yang dimainkan oleh Orkes Keroncong Irama Jakarta menjadi lebih tertata. Lagu-lagu yang diaransemen biasanya meliputi lagu langgam, lagu ekstra, dan lagu-lagu yang diadaptasi 
dari kesenian Gambang Kromong. Untuk lagulagu ekstra dilakukan arransemen meliputi intro dan interlude saja. Namun, untuk lagu keroncong asli dan stambul dimainkan berdasarkan pakem yang ada.

Berdasarkan wawancara yang kami lakukan terhadap personil Orkes Keroncong Irama Jakarta, salah satu tujuan berdirinya Orkes Keroncong Irama Jakarta adalah untuk melestarikan musik keroncong Jakarta dan memasyarakatkan musik keroncong Jakarta khususnya kepada generasi muda. Menurut Cecep Sumarlin, tujuan ini menjadi sangat penting mengingat keroncong Jakarta semakin sedikit yang memainkan. Hal yang dikhawatirkan seandainya tidak dilestarikan akan menjadi punah di kemudian hari. Kedudukan musik keroncong masih dianggap sebagai musik yang berpijak dari tradisi seni pertunjukan rakyat sehingga pengembangannya tidak seramai genre musik yang lain, (Supiarza, H. Sobarna, C. Sukmayadi, Y . Mulyadi, 2018). Terutama Rusmanto, ia bertekad akan terus memainkan irama musik keroncong Jakarta karena keroncong Jakarta merupakan salah satu budaya musik yang berkembang di Jakarta dan merupakan warisan orang tuanya.

\section{Pola Permainan Dobel Engkel}

Perbedaan menonjol antara keroncong Jakarta di Orkes Keroncong Irama Jakarta dengan keroncong yang lain, terletak pada pola permainannya. Keroncong Jakarta memiliki empat pola permainan dan pola permainan tersebut diterapkan dalam lagu-lagu tergantung jenis lagunya. Salah satu pola yang sering dimainkan oleh Orkes Keroncong Jakarta adalah pola permainan dobel engkel. Pola permainan dobel engkel ini sebetulnya merupakan dua pola yang berbeda, yakni pola engkel dan pola dobel. Keduanya dimainkan dalam dua bar berturut-turut secara bergantian. Dalam bar bernomor ganjil, pola yang dimainkan adalah pola engkel dan pada bar bernomor genap dimainkan dengan pola dobel. Kedua pola ini terus diulang sampai akhir lagu. Peneliti beranggapan pola dobel engkel yang dimainkan bergantian dalam dua bar berturut-turut memiliki kesan seolah-olah bersahutan.
Pada permainan keroncong Jawa (Solo), sebetulnya pola dobel dan engkel juga dimainkan, namun yang membedakannya adalah pola dobel engkel pada keroncong Jawa (Solo) dimainkan secara terpisah. Penggunaan pola engkel dalam keroncong Jawa (Solo), Setiawan menyebutkan "pada saat akan memasuki permulaan lagu, pola permainan $c u k$ dan cak kembali lagi ke irama engkel'( Setiawan, 2011). Berbeda dengan keroncong Jakarta yang selalu memainkan pola dobel dan engkel pada bagian permulaan lagu, bridge, dan reff. Pola permainan engkel dalam keroncong Jawa ini pun dimainkan juga pada bagian reff dan senggaan yang biasanya digunakan untuk intro, seperti yang dikatakan oleh Setiawan, "pada bagian reff, pola yang dimainkan kembali ke pola irama engkel' (Setiawan, 2011). Harun Rusli mengatakan, "Lagu keroncong itu dobel engkel. Ciri khas keroncong Jakarta itu dobel engkel' (Wawancara, 20 September 2016).

Dalam keroncong Jakarta, pada bagian senggaan yang digunakan untuk intro dalam lagu keroncong asli, biasanya hanya dimainkan dengan pola dobel saja sampai akhir lagu. Harun Rusli mengatakan, "Udah rumusnya gitu bagian mau akhir lagu dobel panjang." (Wawancara, 12 Desember 2016). Berdasarkan pakem yang terdapat dalam pola permainan dobel engkel di keroncong Jakarta, pada bagian permulaan lagu sampai reff, pola yang dimainkan adalah dobel engkel, namun ketika memasuki bagian senggaan yang biasanya digunakan untuk intro pola permainan yang dimainkan hanya dobel saja sampai interlude. Sedikit berbeda dengan keroncong Jawa (Solo). Dalam keroncong Jawa (Solo), terkait penggunaan pola dobel, Setiawan (2011) mengatakan, "pada saat memasuki bagian bridge terjadi perpindahan dari irama engkel ke dobelan... pada pengulangan lagu nya pun terus dari awal pengulangan lagu sampai akhir lagu menggunakan irama dobelan.” Dalam bagian senggaan terkadang hanya dimainkan pola dobel saja, sama halnya seperti keroncong Jakarta.

\section{Pola Permainan Dobel Balik}

Pada pola permainan dobel balik alat musik keroncong dimainkan secara sinkop dalam hitungan arsis dengan not 1/16 di setiap barnya, 
pola permainan ini terus dimainkan sampai akhir lagu. Hal ini menjadikan pola permainan dobel balik menjadi terasa up beat karena pengaruh dari permainan alat musik keroncong tersebut. Sebagai contoh, peneliti mengambil lagu "Cente Manis". Dalam lagu "Cente Manis", alat musik keroncong dimainkan secara up beat, tanda notasi (1) juga alat musik tenor yang dimainkan lebih up beat dari sebelumnya dapat dilihat pada tanda notasi (2) (lihat Gambar3). Bentuk variasi dari cara memainkan alat musik tenor bertujuan untuk mengimbangi permainan alat musik keroncong, sehingga dari permainan kedua alat musik ini kesan up beat yang ditimbulkan semakin kental.

\section{Pola Permainan Format}

Salah satu pola permainan yang sering dimainkan oleh Orkes Keroncong Irama Jakarta adalah pola permainan dengan format yang hampir sama dengan pola permainan Keroncong Tugu. Pola ini berkaitan dengan penyebaran musik keroncong di Batavia.

Pola permainan format hampir sama dengan pola permainan pada Keroncong Tugu dan musik keroncong jenis ini yang merupakan cikal bakal dari musik keroncong yang berkembang di Jakarta. Beberapa hal yang membedakan antara kedua pola permainan format dengan pola permainan Keroncong Tugu, salah satunya terletak pada alat yang digunakan. Dalam Keroncong Tugu alat yang digunakan adalah machina dan prounga, sedangkan dalam keroncong Jakarta alat yang digunakannya adalah keroncong dan tenor. Cara memainkan alat musik keroncong dalam Kroncong Jakarta hampir sama dengan cara memainkan machina dan prounga

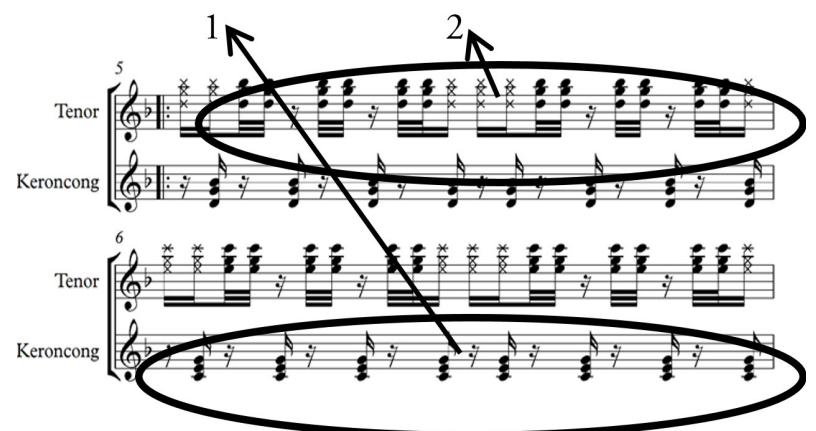

Gambar 3. Permainan Dobel Balik pada alat musik Keroncong dan Tenor dalam lagu "Cente Manis" bar 5-6. (Transkripsi: Peneliti, 2016) yaitu dengan cara diprung atau digaruk (rasguaedo). Hal yang membedakanya dengan keroncong Jakarta terletak pada alat musik keroncong yang tidak selalu dimainkan dengan cara digaruk selayaknya machina dan prounga. Terkadang, alat musik keroncong dimainkan juga dengan teknik strumming menggunakan pick.

Untuk alat musik tenor dalam pola permainan format cenderung dimainkan dengan teknik strumming dengan menggunakan pick. Namun, teknik tersebut tidaklah selalu digunakan di setiap lagu. Alat musik tenor terkadang dimainkan juga dengan cara dipetik satu-satu di setiap senar dalam akord yang dimainkan seperti pola permainan yang lainnya. Fenomena yang ditemukan bahwa meskipun pola permainan ini merupakan imitasi dari permainan Keroncong Tugu, para seniman Keroncong Jakarta tetap mempertahankan identitas mereka dalam memainkan keroncong. Hal itu terlihat pada permainan alat musik tenor yang terkadang juga dimainkan dengan cara dipetik satu-satu.

Selain alat musik yang digunakannya berbeda, teknik yang digunakan untuk memainkan alat musik keroncong dan tenor pun sedikit berbeda dengan alat musik machine dan prounga, khususnya alat musik tenor yang dimainkan dengan cara strumming. Hal tersebut tentu saja berdampak pada warna suara yang dihasilkan oleh kedua jenis keroncong ini, meski pola permainan yang dimainkan hampir sama namun dari segi alat musik dan cara memainkan sedikit berbeda, sehingga berbeda pula pada warna suara yang dihasilkan. Untuk melihat pola permainan format dalam keroncong Jakarta, berikut adalah pola permainan format pada lagu "Jali-Jali".

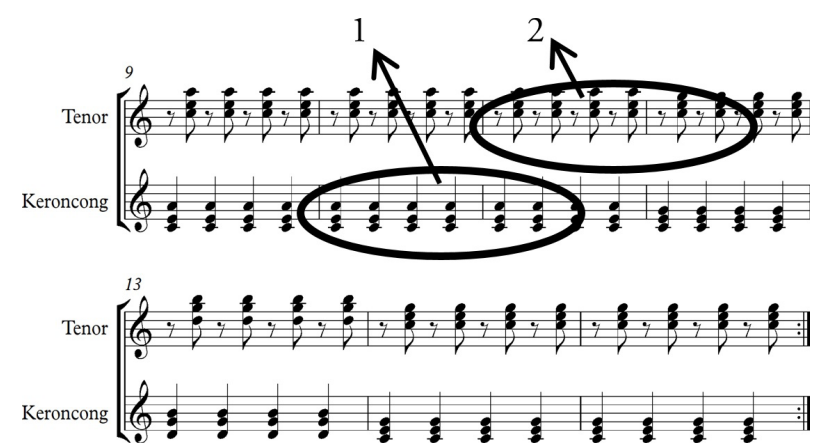

Gambar 4. Notasi pola permainan Machina dan Prounga dalam lagu "Sambel Cobek" oleh Krontjong Tugu bar 10-17. (Transkripsi: Peneliti, 2016) 
Pada Gambar 5 dapat dilihat bahwa pola permainan machina dan prounga pada Keroncong Tugu memiliki kesamaan dengan permainan alat musik keroncong dan tenor dalam pola permainan format, yaitu sama-sama dimainkan pada hitungan thesis untuk prounga yang ditandai (1) dan keroncong sementara hitungan arsis untuk machina yang ditandai (2) dan tenor, pola ini kemudian menciptakan bunyi seperti saling bersahutan.

\section{Pola Permainan Tempo Dulu}

Pola permainan tempo dulu sebetulnya hampir sama dengan pola permainan format yang telah dibahas sebelumnya. Hanya saja, hal yang membedakannya terletak pada materi lagu yang dibawakan dan juga pola permainan alat musik keroncong sedikit berbeda. Dalam pola permainan tempo dulu, alat musik keroncong dimainkan dengan not $1 / 8$ pada hitungan thesis dan arsis pada setiap barnya dengan teknik strumming. Pola ini terjadi dikarenakan oleh sebelumnya dalam musik keroncong Jakarta belum ada alat musik tenor.

Pada saat diwawancarai, Harun Rusli mengatakan, "Jadi waktu kalo jaman Belanda, kita maennya ya paling berempat. viul ya to, cello ama keroncong, belum ada tenor." (Wawancara, 20 September 2016). Dalam hal ini ditemukan pola untuk mengisi kekosongan pada saat belum adanya alat musik tenor dengan memainkan alat musik keroncong pada hitungan thesis dan arsis. Hal tersebut terus-menerus dilakukan yang pada akhirnya menjadi sebuah ciri dalam pola permainan tempo dulu. Setelah ada penambahan alat musik tenor, cara memainkan alat musik keroncong dalam pola permainan tempo dulu tidak berubah, tetap dimainkan dalam hitungan thesis dan arsis dan alat musik tenor dimainkan dalam hitungan arsis. Dalam

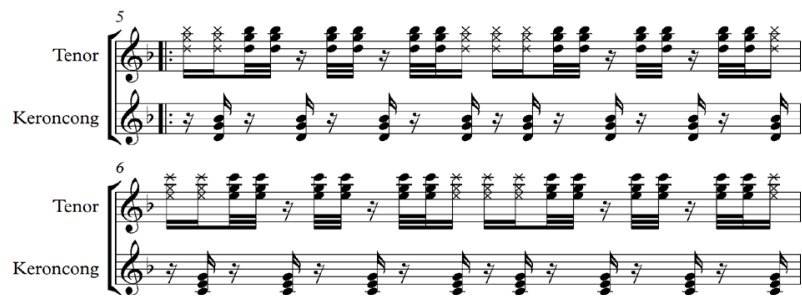

Gambar 5. Notasi pola permainan Dobel Engkel pada alat musik Keroncong dan Tenor dalam lagu "Cente Manis" bar 5-6. (Transkripsi: peneliti, 2016) pola permainan tempo dulu di beberapa bagian alat musik keroncong dimainkan secara sinkop. Sebetulnya hal tersebut bukan termasuk sinkop. Harun Rusli mengatakan, "Oo kaya itu bukan keharusan berhenti tapi jeda antara mau pindah akord." (Wawancara, 12 Desember 2016). Pola ini dilakukan karena keterbatasan pemain dalam memainkan alat musik keroncong. Dalam lagu ini alat musik keroncong terus dimainkan dalam hitungan thesis dan arsis. Apabila akan berpindah akor, alat musik keroncong dimainkan secara terus menerus dalam hitungan thesis dan arsis. Suara yang dihasilkan akan kurang baik sehingga diberikanlah jeda setiap akan berpindah akord. Selain itu, hal tersebut akan mempermudah tangan kiri ketika berpindah akor. Karena cara memainkannya seperti itu, seolah-olah alat musik keroncong dimainkan secara sinkop, padahal hal tersebut tidak terjadi sama sekali. Alasan yang awalnya teknis kemudian dilakukan terus-menerus sehingga hal tersebut menjadi ciri dan karakteristik dalam memainkan pola tempo dulu pada orkes irama jakarta. Sampai saat ini, cara memainkan alat musik keroncong dan tenor tetap dipertahankan dengan pola keroncong. Selain itu, alat musik keroncong dimainkan dalam hitungan thesis dan arsis sedangkan alat musik tenor dimainkan hanya pada hitungan arsis. Selain itu, terdapat bagian alat musik keroncong dan tenor yang dimainkan bersama dalam hitungan arsis di setiap barnya. Kesan saling bersahutan antara kedua alat musik ini terasa lebih tebal dikarenakan oleh alat musik keroncong dimainkan juga pada hitungan arsis bersamaan dengan alat musik tenor.

\section{Penerapan Pola Permainan Dobel Engkel}

Dalam keroncong Jakarta, pola permainan dobel engkel biasanya dimainkan untuk mengiringi lagu-lagu keroncong asli, seperti keroncong "Moresko", keroncong "Bandar Jakarta" dan lagu keroncong "Miss Ribut". Namun tidak semua lagu keroncong asli diiringi dengan pola permainan dobel engkel, contohnya Keroncong "Pasar Gambir" dan Keroncong "Air Laut" diiringi dengan pola permainan tempo dulu. Lain halnya dengan pola permainan dobel engkel yang dimainkan dalam keroncong Jawa (Solo). Pada keroncong Solo, pola 
permainan dobel engkel tidak hanya dimainkan untuk lagu-lagu keroncong asli saja, namun dimainkan juga pada lagu-lagu langgam, stambul, dan juga lagu-lagu ekstra. Hal tersebut terjadi karena dalam keroncong Jawa (Solo) hanya terdapat pola permainan engkel dan dobel saja, sedangkan pada keroncong Jakarta pola permainannya terdapat lebih banyak pola permainan. Terdapat empat pola permainan sehingga setiap membawakan lagu yang berbeda akan berbeda pula pola permainan yang dimainkan.

\section{Penerapan Pola Permainan Dobel Balik}

Pola permainan selanjutnya adalah pola permainan dobel balik. Pola permainan dobel balik ini dimainkan untuk mengiringi lagu-lagu berirama relatif cepat, lagu-lagu berkesan riang, dan juga lagu-lagu adaptasi dari kesenian gambang kromong. Karena pola permainan dobel balik terkesan up beat, lagu-lagu yang dibawakan biasanya lagu-lagu berirama relatif cepat. Perasaan up beat tersebut timbul karena dalam pola permainan dobel balik alat musik keroncong dimainkan secara sinkop dalam hitungan arsis dengan not $1 / 16$. Oleh karena itu, dalam pola permainan ini lagu-lagu yang diiringi merupakan lagu-lagu yang berirama relatif cepat, terkesan riang dan lagu-lagu yang diadaptasi dari kesenian gambang kromong. Seperti pada Gambar 6 di bawah ini.

Gambar 6 merupakan partitur dari alat musik keroncong dan tenor dalam pola permainan dobel balik dalam lagu "Cente Manis" yang diadaptasi dari lagu kesenian gambang kromong. Setiap memainkan lagu gambang kromong, pola permainan sudah pasti pola permainan dobel balik, karena lagu-lagu gambang kromong iramanya relatif cepat. Hal ini sejalan dengan irama dari pola permainan dobel balik yang berirama relatif cepat dan terkesan upbeat.

Pola permainan ini digunakan juga untuk mengiringi lagu-lagu di luar kebiasaan mereka, seperti lagu atas permintaan penonton atau personil lainnya. Misalnya ketika ada permintaan personil atau penonton yang ingin membawakan lagu di luar jenis musik keroncong dan memiliki irama lambat, maka lagu tersebut tetap terkesan cepat.
Kesan cepat ini disebabkan oleh pola permainan dobel balik memiliki sifat penuh dengan not bernilai 1/16-an.

\section{Penerapan Pola Permainan Format}

Pola permainan format biasanya dimainkan untuk mengiringi lagu-lagu langgam, lagu-lagu ekstra dan lagu lain yang memang disepakati untuk dimainkan dengan pola permainan format. Pola permainan ini hampir sama dengan pola permainan Keroncong Tugu yang dimainkan dengan saling bersahutan dalam hitungan thesis dan arsis.

Sedikit berbeda dengan keroncong Jawa (Solo) yang tetap memainkan pola permainan engkel dan dobel untuk mengiringi lagu jenis apapun. termasuk lagu langgam, stambul dan lagu ekstra. Perbedaan dengan keroncong Jakarta khususnya Orkes Keroncong Irama Jakarta, pada keroncong Jakarta terdapat beberapa pola permainan, sehingga setiap lagu yang dibawakan akan berbeda pula pola permainan yang dimainkannya.

\section{Penerapan Pola Permainan Tempo Dulu}

Pola permainan tempo dulu merupakan pola permainan yang sering digunakan oleh Orkes Keroncong Jakarta untuk mengiringi lagu-lagu lama seperti lagu schoon ver van jou, keroncong pasar gambir, keroncong air laut dan Olesio. Lagu-lagu tersebut merupakan lagu-lagu lama yang sering dimainkan oleh Orkes Keroncong Irama Jakarta dengan menggunakan pola permainan tempo dulu. Apabila dilihat lebih dalam lagi, sebetulnya untuk lagu Keroncong Pasar Gambir dan Keroncong Air Laut, kedua lagu ini memiliki bentuk lagu keroncong asli. Seperti yang telah dikatakan sebelumnya bahwa dalam mengiringi lagu keroncong asli keroncong Jakarta khususnya Orkes Keroncong Irama Jakarta selalu menggunakan pola permainan dobel engkel, namun dalam lagu ini pola permainan yang digunakan adalah pola permainan tempo dulu. Harun Rusli mengatakan, "jadi kalo gaya lama itu ada lagu tertentu yang memang harus dimainkan seperti itu" (Wawancara, 20 September 2016).

Berdasarkan pernyataan Harun Rusli disimpulkan bahwa dalam permainan ada 
beberapa lagu yang memang harus dimainkan dengan menggunakan pola permainan tempo dulu. Meskipun bila dilihat dalam bentuk lagunya, lagu tersebut mempunyai bentuk lagu keroncong asli, langgam, stambul ataupun lagu ekstra.

\section{Penutup}

Berdasarkan hasil penelitian diperoleh simpulan bahwa setiap seniman keroncong Jakarta khususnya Orkes Keroncong Irama Jakarta selalu dipengaruhi budaya yang berkembang disekitar dan pengalaman empiris para senimannya. Selanjutnya ihwal memainkan alat musik keroncong dan tenor, bermula dari keterbatasan keterampilan dalam memainkan alat musik, kemudian keterbatasan tersebut justru menjadi suatu gaya tersendiri dalam pola permainan alat musik keroncong dan tenor dan memperkaya khasanah pola permainan alat musik keroncong itu sendiri. Dalam aspek permainan terdapat konsep saling berpasangan, konsep ini ada pada alat musik keroncong dan tenor, (call and respond) saling bersahutan seolah-olah pasangan antara kalimat tanya dan jawab. Kemudian dilihat dari salah satu pola permainannya yaitu dobel engkel selalu dimainkan berturut-turut antara pola engkel dan dobel dan tidak pernah dibawakan hanya satu pola saja dalam satu lagu, konsep berpasangan ini yang terdapat dalam keroncong Jakarta. Konsep saling berpasangan pun terlihat pada lirik lagu yang sebagian besar liriknya berupa pantun, dalam pantun sudah pasti ada kalimat-kalimat berpasangan antara sampiran dan isi. Juga penyajian pola permainan yang terdapat dalam keroncong Jakarta selalu dipasangkan dengan lagu-lagu yang berbeda sesuai dengan jenisnya. Inilah karakter yang dimiliki oleh orkes keroncong irama Jakarta yang tidak dimiliki oleh orkes keroncong lainnya.

\section{Kepustakaan}

Aan Prabowo, H. (2013). Analisis Pemanfaatan Buku Elektronik (E-Book) Oleh Pemustaka di Perpustakaan SMA Negeri 1 Semarang. Jurnal Ilmu Perpustakaan, 2(2), 1-9.

Alfian, M. (2013). Keroncong Music Reflects the Identity of Indonesia. Tawarikh: International
Journal for Historical Studies, 4(2), 171-186.

B, J. B. (1979). Mengenal Keroncong dari Dekat. Jakarta: Akademi Musik Lembaga Pendidikan Kesenian Jakarta.

Destiana, E. (2012). Keroncong Stamboel Sebagai Bentuk Akulturasi Budaya Urban. PEDAGOGIA: Jurnal Pendidikan, 1(2), 153. https://doi.org/10.21070/pedagogia.v1i2.38

Ganap, V. (2000). Tugu keroncong music: hybrid genre of Portuguese sojourn. Jurnal Pengetahuan Dan Penciptaan Seni Seni, 2(4), 213-228.

Ganap, V. (2011). Keroncong Toegoe. Yogyakarta: BP ISI.

Harmunah. (1996). Musik keroncong sejarah, gaya dan perkembangan. Yogyakarta: Pusat Musik Liturgi.

Harwanto, D. C. (2018). Bentuk dan Struktur Kesenian Kentrung di Jepara. Resital, 19(1), $35-45$.

Heins, E. (1975). Kroncong and Tanjidor - Two Cases of Urban Folk Music in Jakarta. Asian Music, 7(1), 20-32.

Kautzar, A. (2019). Karakteristik Bentuk Musik Melayu Di Kota Palembang Pada Lagu Melati Karangan. Resital: Jurnal Seni Pertunjukan, 18(2), 88-94. https://doi.org/10.24821/ resital.v18i2.1926

Kristianto, J. (2007). Gitar Pedia-Buku Pintar Gitaris. Jakarta: Gramedia Pustaka Utama.

Laksono, K. L. (2015). Musik Hip-Hop sebagai Bentuk Hybrid Culture dalam Tinjauan Estetika. Resital: Jurnal Seni Pertunjukan, 16(2), 75-83. https://doi.org/10.24821/ resital.v16i2.1507

Lei Ouyang Bryant. (2005). Music, Memory, and Nostalgia: Collective Memories of Cultural Revolution Songs in Contemporary ChinaNo Title. China Review, 5(2), 151-175.

Lisbijanto, H. (2013). Musik Keroncong. Jakarta: Graha Ilmu.

Mack, D. (1995). Apresiasi Musik, Musik Populer. Yogyakarta: Yayasan Utama Nusatama.

Margaret J. Kartomi, David Goldsworthy, Catherine Falk, B. K. (1978). Studies in Indonesian music. Centre of Southeast Asian Studies, Monash UniversityMonash University. 
Marti, J. (2014). Hybridization and Its Meanings in the Catalan Musical Tradition, (January 2002).

Nurkhalis. (2012). Konstruksi Teori Paradigma Thomas S. Kuhn. Islam Futura, XI(2), 80-99.

Rachman, A., \& Utomo, U. (2017). "Sing Penting Keroncong” Sebuah Inovasi Pertunjukkan Musik Keroncong di Semarang. Jurnal Pendidikan Dan Kajian Seni, 3(1). https:// doi.org/10.30870/jpks.v3i1.4066

Ratna, N. K. (2016). Metode Penelitian. Yogyakarta: Pustaka Pelajar.

Setiawan, D. (2011). Pola Permainan Cuk dan Cak dalam Keroncong Asli di RRI Bandung. Universitas Pendidikan Indonesia.

Siagian, R. (2013). Penyerbukan Silang Kebudayaan Musik Nusantara. Kongres Kebudayaan Indonesia (KKI) 2013. Yogyakarta.

Suadi, H. (2017). Djiwa Manis Indoeng Disajang, Musik Dan Dunia Hiburan Tempo Dulu. Bandung: PT. Kiblat Buku Utama.

Sunarto, B. (2013). Konsepsi Filosofis di Balik Musik Sholawat Campur ngaji. Panggung, 23(2), 117-135. https://doi.org/10.26742/ panggung.v23i 2.92

Supiarza, H. Sobarna, C. Sukmayadi, Y . Mulyadi, R. . (2018). The Prospect and Future of Youth Kroncong Group at Universitas Pendidikan Indonesia in Bandung. Harmonia: Journal of Arts Research and Education, 18(1), 100110. https://doi.org/10.15294/harmonia. v18i1.15524

Supiarza, H. Sobarna, C. (2019). “Jamaican Sound
Keroncong" Cultural Intermixture Product in the Global Era: A Communication Study on the Spread of Keroncong in the Young Generation of Bandung. Humaniora, 10(1). Supriando. (2016). Pertujukan Musik Grande Ouverture, Asturias, dan Karak Lilisan dalam Solo Gitar. Jurnal Puitika, 12(2), 160-173. Widhyatama, S. (2012). Pola Imbal Gamelan Bali Dalam Kelompok Perkusi Cooperland Di Kota Semarang. Jurnal Seni Musik, 1(1), 59-67.

Wijayanto, I., \& Dwifebrianti, R. (2013). Jenis Tipe Jangkauan Suara Pada Pria Dan Wanita Menggunakan Metoda Mel-Frequency Cepstral Coefficient. In Konfrensi Nasional Sistem dan Informatika (pp. 2-10).

Yampolsky, P. B. (2010). Kroncong Revisited: New Evidence from Old Sources. Archipel, 79(1), 7-56. https://doi.org/10.3406/ arch.2010.4159

Yampolsky, P. B. (2013). Music and media in the Dutch East Indies: Gramophone records and radio in the late colonial era, 1903--1942. ProQuest Dissertations and Theses.

\section{Informan}

Harun Rusli. Lahir di Jakarta tanggal 9 Januari 1943; Pemain alat musik tenor dan pimpinan Orkes Keroncong Irama Jakarta

Kelik S. Ponco. Lahir di Yogyakarta tanggal 10 Januari 1951; pemain flute dan arranger Keroncong Irama Jakarta. 


\section{WRITING INSTRUCTIONS}

\section{Title}

[Title must succinctly describes the contents of the research article and attract the academic readers. The title consists of 8-12 words, not including definite article (the) and indefinite article ( $a$, an). Use the phrases, not sentence.].

\section{Author(s)}

[Author must fill out author's profile that consist of author First, Middle and Last Name (If author only uses one name, fill the first name and last name with the same name), Gender, Initial, Username, Password, Affliation (University/Institution), E-mail, Mailing Address (complete address of affiliation), Country and Bio Statement. Author(s) must follow the journal template which can be downloaded at http://journal.isi.ac.id/index.

php/resital

\section{ABSTRACT}

The abstract is a summary of the article. It is consist of aim/goal/problem of research, research methods, results and discussion, and conclusion. Implications or recommendation can be added in the abstract. The abstract must be written in 150-250 words. The abstract must not contain lengthy background information and have no reference to figure, table, equation, any bibliographical reference either coming within or other article. The language of abstract must be clear and concise. It is a stand-alone summary in one paragraph.

Keywords: it contains 3-5 important words that are taken from the title and the content of the paper

\section{Introduction}

The introduction show what is already known from the previous studies, defines the importance of the study, literature review, and state the research question. In order to understand what is already known from the previous study, the introduction must consist of discussing the relevant journal article (with citation) and summarizing the current understanding of the problem encounter. The methods explain clearly how the author carried out the research. The method must describe the research design clearly, the replicable research procedures, describe how to summarize and analyze the data.

\section{Result and Discussion}

The result section shows objectively the presentation of the research key results without any interpretation using text, tables and figures. The result section begins with text, presenting the key finding, and referring to the tables and figures. The table must not print screen, specific numerical values, compare and contrast values, and minimum of 2 row and column. The figures must clear (provide original file as supplementary file in article submission), highlight trends, pattern, and relationship. The result section must present how the author ensure the data validity and reliability

The discussion section shows how the author interprets the results in light of what are already known, and to explain the new understanding of the problem after taking your results into consideration. The discussion must connect with the Introduction so it tells how your study contributes to the body of knowledge and society.

Tabel 1. Student Distribution Frequency

\begin{tabular}{|c|c|c|c|c|}
\hline No. & Interval & Frequency & $\%$ & Category \\
\hline 1. & $85-100$ & 59 & 28.36 & Very Good \\
\hline 2. & $75-84$ & 93 & 44.71 & Good \\
\hline 3. & $65-74$ & 37 & 17.78 & Average \\
\hline 4. & $55-65$ & 19 & 09.15 & Bad \\
\hline & Jumlah & 208 & 100.00 & \\
\hline
\end{tabular}

Figure 1. Speed Changing Tool
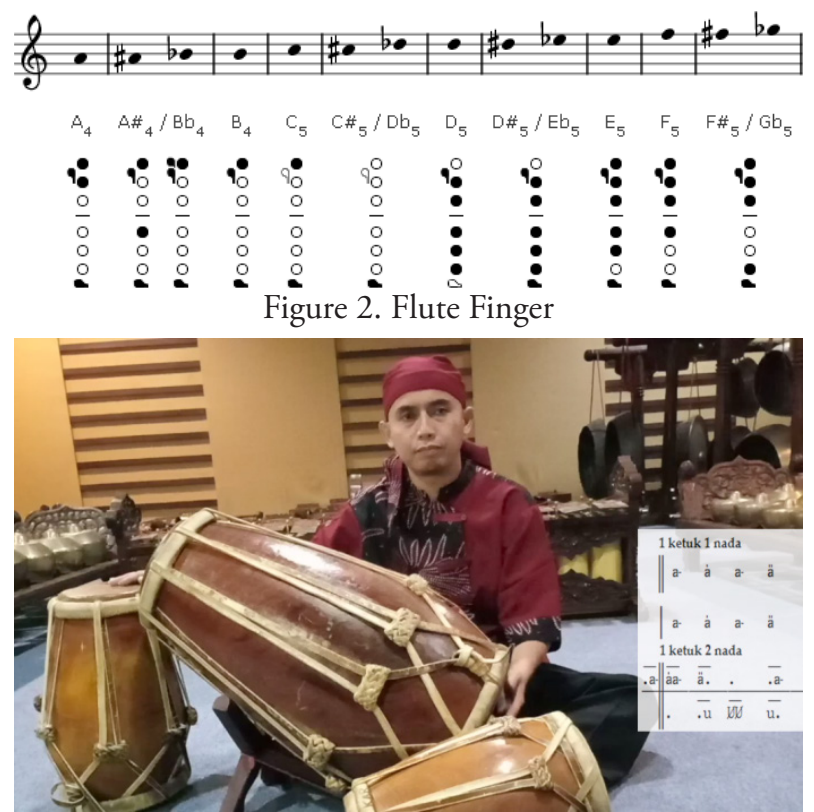

Figure 3. Kendang Practice (Source: Asep, 2017) 


\section{Conclusion}

The conclusions section show the answer or clarification of the research questions and opportunities for future research.

\section{References}

The reference must consist of $80 \%$ from relevant and recent primary sources (such as article of journal or conference from last 5 years). The reference must be written in APA style and using reference manager software Mendeley.

\section{Journal Article}

B Budi, D. S. U., Soedarsono, R. M., Haryono, T., \& Narawati, T. (2014). Angklung Dogdog Lojor pada Upacara Seren Taun. Resital: Jurnal Seni Pertunjukan, 15(2), 139-151. Retrieved from http://www.journal.isi.ac.id/index.php/ resital/article/view/848.

\section{Book}

Suharto, Edi. (2014). Membangun Masyarakat Memberdayakan Rakyat: Kajian Strategis Pembangunan Kesejahteraan Sosial \& Pekerjaan
Sosial. Bandung: Refika Aditama.

\section{Thesis, Dissertation, and Research Reports}

Prasetya, H.B. (2012). Melesed dan Nggandhul dalam Karawitan Pedalangan Gaya Yogyakarta. Universitas Gadjah Mada Yogyakarta.

\section{Conference Proceedings}

Muthmainnah, L. (2017). Perancangan Kampanye Penanggulangan Dampak Lagu Dewasa Terhadap Anak-Anak. e-Proceeding of Art and Design, 4(2), 138-146.

\section{Audio/Video}

Sugito, Hadi. (2005). Lakon Semar Gugat. (Cassete). Semarang: Fajar Record.

\section{Informant}

Handiman (79 years old). Angklung Craftman who is the student of Daeng Sietigna. Jln. Surapati No. 95 Bandung 40123.

\section{Article Submission}

Article should be uploaded through Open Journal System of http://journal.isi.ac.idlindex.php/resital 